\title{
Translation, cross-cultural adaptation and validation of the Finnish Diabetes Risk Score (FINDRISC) for use in Brazilian Portuguese: questionnaire validity study
}

\author{
Adrianny Larissa Oliveira Conceição', Natália de Castro Corrêa", Patrícia Rodrigues Ferreiral', Adriana Sousa Rêgo"v, \\ Fabricio Brito Silvav , Sarah Tarcísia Rebelo Ferreira de Carvalhov", Rosane da Silva Dias ${ }^{\mathrm{VII}}$, Bruna Katarine Beserra Paz ${ }^{\mathrm{VII}}$, \\ Viviane Chaves de Carvalho Rocha' ${ }^{1 \mathrm{X}}$, Daniela Bassi-Dibai ${ }^{\mathrm{X}}$
}

Universidade Ceuma (UNICEUMA), São Luís (MA), Brazil

'Undergraduate Student, Department of Physical Therapy, Universidade Ceuma (UNICEUMA), São Luís (MA), Brazil.

(D) orcid.org/0000-0002-4374-2413

"Master's Degree Student, Postgraduate Program on Program Management and Healthcare

Services, Universidade Ceuma (UNICEUMA), São Luís (MA), Brazil.

(D) orcid.org/0000-0003-1121-7953

'I'MSc. Professor, Department of Physical Therapy, Universidade Ceuma (UNICEUMA), São Luís (MA), Brazil.

(D) orcid.org/0000-0002-4757-3370

vPhD. Professor, Postgraduate Program on Program Management and Healthcare Services, Universidade Ceuma (UNICEUMA), São Luís (MA), Brazil.

(D) orcid.org/0000-0002-2494-030X

vphD. Professor, Postgraduate Program on Environment, Universidade Ceuma (UNICEUMA), São Luís (MA), Brazil.

(D) orcid.org/0000-0002-9878-0206

uphD. Professor, Department of Physical Therapy,

Universidade Ceuma (UNICEUMA), São Luís

(MA), Brazil.

(D) orcid.org/0000-0002-6041-3320

viPhD. Coordinator, Postgraduate Program on

Program Management and Healthcare Services, Universidade Ceuma (UNICEUMA), São Luís

(MA), Brazil.

(D) orcid.org/0000-0001-6153-9104

VIIPhD. Professor, Department of Physical

Therapy, Universidade Ceuma (UNICEUMA), São Luís (MA), Brazil.

(D) orcid.org/0000-0001-8295-3005

IXMD, MSc. Professor, Department of Medicine,

Universidade Ceuma (UNICEUMA), São Luís

(MA), Brazil.

(D) orcid.org/0000-0002-2498-3289

xphD. Professor, Postgraduate Program on Program Management and Healthcare Services, Universidade Ceuma (UNICEUMA), São Luís (MA), Brazil.

(D) orcid.org/0000-0002-6140-0177

KEY WORDS (MeSH terms):

Surveys and questionnaires.

Reproducibility of results.

Psychometrics.

Public health

AUTHORS' KEY WORDS:

Questionnaires.

Diabetes.

Questionnaire validity.

\begin{abstract}
BACKGROUND: The Finnish Diabetes Risk Score (FINDRISC) is a questionnaire that was developed by Finnish researchers to track the risk of diabetes.

OBJECTIVE: To translate, cross-culturally adapt and validate the FINDRISC for use in Brazilian Portuguese. DESIGN AND SETTING: Questionnaire validity study conducted at a private university.

METHODS: The Brazilian version of the FINDRISC was developed through the processes of translation, back-translation, committee review and pre-testing. Test-retest reliability was measured using the intraclass correlation coefficient (ICC), kappa coefficient, standard error of measurement (SEM) and minimum detectable change (MDC). Internal consistency was measured using Cronbach's alpha. For construct validity, the total score of the FINDRISC was correlated with the Diabetes Knowledge Scale (DKN-A) and Diabetes Mellitus Risk Questionnaire (QRDM). Ceiling and floor effects were also evaluated in the present study. RESULTS: For construct validity and floor and ceiling effect measurements, a total sample of 107 participants was used. For reliability, a subsample of 51 participants out of the total sample was used. We identified adequate values for reliability (kappa $\geq 0.79$ and ICC $=0.98$ ) and internal consistency (Cronbach's alpha $=0.84$ ). Regarding the error inherent in the FINDRISC, we found SEM $=8.02 \%$ and MDC $=22.44 \%$. There were significant correlations between the FINDRISC and the QRDM $(r=0.686)$ and DKN-A $(r=-0.216)$. No ceiling or floor effects were found.

CONCLUSION: The Brazilian version of the FINDRISC has adequate psychometric properties that are in accordance with the best international recommendations.
\end{abstract}

\section{INTRODUCTION}

Recently, the International Diabetes Federation reported that the number of individuals with type 2 diabetes mellitus (T2DM) had increased worldwide, especially in Brazil, which placed this country in fifth place among the countries with the most people with diabetes mellitus. ${ }^{1}$

Given this reality, strategies are being sought in an attempt to easily and cost-effectively screen individuals with high potential to develop T2DM, in order to implement preventive measures against the onset of the disease. In this context, use of questionnaires has been an ally in screening for several other diseases. ${ }^{2-5}$

A few questionnaires directed towards people with T2DM have been validated for Brazilian Portuguese, including the Diabetes Quality of Life Measure, ${ }^{6}$ Diabetes Mellitus Knowledge and Attitude Questionnaire ${ }^{5}$ and Diabetes Self-Care Activities. ${ }^{7}$ With regard to the risk of developing T2DM, there is no validated questionnaire for use in Brazilian Portuguese for these purposes.

The Finnish Diabetes Risk Score (FINDRISC) is a questionnaire that was developed in Finnish and English in 2003 by Finnish researchers. It had the aims of tracking the risk of diabetes and stimulating the adoption of measures to prevent the onset of T2DM, especially for individuals who are at increased risk of the disease, but without the need for low-cost laboratory tests. ${ }^{8}$ Some articles using the FINDRISC have already been published in Brazilian Portuguese, ${ }^{9,10}$ even without proper translation, cross-cultural adaptation or validation of the questionnaire for this language. However, the FINDRISC has already been validated for other languages, including those spoken by the populations of Spain, ${ }^{11}$ Greece, ${ }^{12}$ Venezuela, ${ }^{13}$ Colombia, ${ }^{14}$ Hungary,,${ }^{15}$ Germany, ${ }^{16}$ Jordan,,${ }^{17}$ China, ${ }^{18}$ Norway ${ }^{19}$ and Slovenia. ${ }^{20}$ 


\section{OBJECTIVE}

Considering the importance of instruments that track the risk of developing T2DM, for the context of public health, the aim of this study was to translate, cross-culturally adapt and validate the FINDRISC for use in Brazilian Portuguese.

\section{METHODS}

\section{Study design and ethics}

This was a cross-sectional study on the translation, cross-cultural adaptation and validation of a questionnaire. It was conducted in accordance with the Guidelines for the Process of Cross-Cultural Adaptation of Self-Report Measures ${ }^{21}$ and the COnsensus-based Standards for the selection of health Measurement INstruments (COSMIN). ${ }^{22}$ Authorization for analysis of the psychometric properties of the FINDRISC in Brazilian Portuguese was granted via e-mail by the authors of the original version of the questionnaire (Dr. Jaana Lindstrom and Dr. Jaakko Tuomilehto).

This study was approved by the Research Ethics Committee of our institution, under number 2.853.570, on August 29, 2018. All the participants validated their participation by signing a free and informed consent statement. These participants were recruited from the university community in the city of São Luís (MA), Brazil, and from a community associated with this city. Announcements regarding this study were disseminated through pamphlets and social media.

\section{FINDRISC translation and cross-cultural adaptation}

The process of translation and cross-cultural adaptation of the FINDRISC for use in Brazilian Portuguese followed the criteria of Beaton et al. ${ }^{21}$ and was performed in five phases as described below:

1) Translation: two independent translators, both with Brazilian Portuguese as their mother tongue and fluent in English, translated the original version of the questionnaire into Brazilian Portuguese;

2) Synthesis of translations: after discussions and revisions, the two translators, under observation of one of the researchers, produced a synthesis from the two versions of the independently translated questionnaire, thus resulting in a combined version in a consensual manner;

3) Back-translation: two independent translators (without technical knowledge of health issues), both with English as the mother tongue and fluent in Portuguese, translated the Portuguese version of the questionnaire back to English, without previous knowledge of the original version of the questionnaire;

4) Expert committee review: six diabetes specialists, along with the four translators of this study, reviewed the original version and the translated, synthetized and back-translated versions, and defined the pre-final version of the FINDRISC;
5) Pre-final version test: the pre-final version of the questionnaire was administered to 30 individuals without a diagnosis of diabetes and with Portuguese as their mother tongue. The respondents' comprehension of the items and responses in the FINDRISC was evaluated.

\section{Participants}

The sample size for this validation study was based on COSMIN, and a minimum of 100 individuals was recommended. ${ }^{23}$ The eligibility criteria that we used were that the participants could be of either sex, without any diagnosis of type 1 or type 2 diabetes mellitus, aged over 24 years and under 64 years, and without cognitive deficits or any other limitations that would make it impossible for them to respond to the questionnaire.

\section{FINDRISC}

The FINDRISC consists of eight items that investigate and rate the risk of developing T2DM within 10 years. The responses to each item are scored according to their influence on the development of the disease. The total score can range from 0 to 26 points and is classified as follows: $\leq 7$ points, low risk ( 1 in 100 people will develop disease); 7 to 11 points, slightly elevated risk ( 1 in 25 people will develop the disease); 12 to 14 points, moderate risk ( 1 in 6 people will develop the disease); 15 to 20 points, high risk ( 1 in 3 people will develop the disease); and $>20$ points, very high risk ( 1 in 2 people will develop the disease).

\section{OTHER QUESTIONNAIRES}

In addition to the FINDRISC, we applied two other questionnaires that had already been adapted and validated for use in Brazilian Portuguese, to ascertain the construct validity. These instruments were:

1) Diabetes Knowledge Scale (DKN-A), a questionnaire that was validated for the Brazilian population by Torres et al., ${ }^{5}$ which is composed of 15 multiple-choice questions on various aspects of general knowledge relating to T2DM. The total score is calculated by assigning one point to each correct answer, and it can range from 0 to 15 . The higher the score is, the greater the respondent's knowledge about T2DM is.

2) Diabetes Mellitus Risk Questionnaire (QRDM), a questionnaire that was validated in the master's degree dissertation of Cruz, ${ }^{3}$ which is composed of seven items, with a total score that can range from 0 to 27 points. The higher the score is, the higher the respondent's risk of developing T2DM is.

\section{Statistical analysis}

Reliability was assessed based on a test-retest model by measuring the kappa coefficient, intraclass correlation coefficient (ICC), standard error of measurement (SEM) and minimum 
detectable change (MDC). Internal consistency was assessed using Cronbach's alpha. The kappa values were interpreted based on the categories defined by Sim and Wright: < 0 , poor; 0.01-0.20, slight; 0.21-0.40, fair; 0.41-0.60, moderate; 0.61-0.80, substantial; and $0.81-1$, almost perfect. ${ }^{24}$ The ICC values were interpreted based on the study by Fleiss: for values below 0.40 , reliability was considered low; between 0.40 and 0.75 , moderate; between 0.75 and 0.90 , substantial; and greater than 0.90 , excellent. ${ }^{25}$ The SEM percentage was interpreted based on the definitions of Ostelo et al.: $5 \%$ or less, very good; greater than $5 \%$ and less than or equal to $10 \%$, good; greater than $10 \%$ and less than or equal to $20 \%$, doubtful; and greater than $20 \%$, negative. ${ }^{26}$

To ascertain the validity of the construct, Pearson's correlation coefficient ( $r$ ) was used to determine the magnitude of the correlations between the FINDRISC and the QRDM, and between the FINDRISC and the DKN-A. The $\mathrm{r}$ values were interpreted in accordance with the COSMIN recommendations: correlations with instruments measuring similar constructs should be $\geq 0.50$; correlations with instruments measuring related but dissimilar constructs should be $0.30-0.50$; and correlations with instruments measuring unrelated constructs should be $<0.30 .^{22}$

Ceiling and floor effects were evaluated in the present study. By definition, these effects occurred when a number of study participants (set as over 15\%) reached the minimum or maximum values of the total score of the questionnaire.

\section{RESULTS}

\section{Sample characterization}

The study consisted of three samples of different sizes. Initially, for the analysis on the pre-test version of the instrument, 30 participants were included. For the assessment of construct validity and measurement of the floor and ceiling effects, a total sample consisting of 107 participants who were evaluated at a single time was used. For determine the reliability of the FINDRISC, a subsample was used, comprising 51 participants from the total sample who were evaluated at two times (test and retest), seven days apart. The sample size used in this validation study was in accordance with international practices for cross-cultural adaptation and validation of questionnaires, as guided by the study of Beaton et al. ${ }^{21}$ and by COSMIN. ${ }^{22}$

The participants' characteristics are described in Table 1, along with the mean scores from the QRDM and DKN-A questionnaires.

\section{Translation and cross-cultural adaptation}

The translation and back-translation processes are described in Table 2. After the two translations performed by Portuguese native speakers, the translations were synthetized, and the translators came to an agreement regarding the definitions for the eight items of the FINDRISC in Brazilian Portuguese. Next, back-translation was performed by two English native speakers. After this phase, there was a meeting involving the translators and a committee of experts, and the synthetized version was accepted unanimously, without any amendments proposed. In this manner, the pre-final version of the FINDRISC was defined.

The pre-final version of the FINDRISC was applied to 30 individuals (24 women, $80 \%$ ) without a diagnosis of diabetes and with Brazilian Portuguese as their mother tongue. The average age of this sample was 49 years (standard deviation, $\mathrm{SD}=10.82$ ), and the average FINDRISC score was 11.56 points $(S D=4.70)$. There was $100 \%$ understanding of the questionnaire items, which thus defined the final version of the FINDRISC in Brazilian Portuguese (Appendices 1 and 2).

\section{Reliability and internal consistency}

Table 3 presents the reliability values item-by-item and the total score of the final version of the FINDRISC in Brazilian Portuguese. We found adequate values for reliability (kappa $\geq 0.66$ and ICC $=0.98$ ) and internal consistency (Cronbach's alpha $\geq 0.82$ ). In addition, in calculating the error inherent to the FINDRISC total score, we found that the values were sufficient, as follows: SEM (absolute) $=0.63$; SEM $(\%)=8.02$; MDC (absolute $)=1.76$; and $\operatorname{MDC}(\%)=22.44$.

\section{Construct validity}

The construct validity was tested by correlating the total FINDRISC score with the scores from the other questionnaires

Table 1. Characteristics of study participants according to study phase

\begin{tabular}{|c|c|c|}
\hline Characteristic & $\begin{array}{l}\text { Reliability phase } \\
\qquad(n=51)\end{array}$ & $\begin{array}{l}\text { Validity phase } \\
\qquad(n=107)\end{array}$ \\
\hline Gender (female) ${ }^{a}$ & $38(74.51 \%)$ & $80(74.8 \%)$ \\
\hline Age (years) $^{b}$ & $36.90(10.67)$ & $42.88(12.35)$ \\
\hline \multicolumn{3}{|l|}{ Schooling ${ }^{\mathrm{a}}$} \\
\hline Elementary education & $3(5.9 \%)$ & $18(16.9 \%)$ \\
\hline High school & $30(58.8 \%)$ & $59(55.1 \%)$ \\
\hline Higher education & $18(35.3 \%)$ & $30(28 \%)$ \\
\hline \multicolumn{3}{|l|}{ Marital status ${ }^{\mathrm{a}}$} \\
\hline Single & 35 (68.6\%) & $60(56.1 \%)$ \\
\hline Married & $14(27.4 \%)$ & $43(40.2 \%)$ \\
\hline Divorced & $1(2.0 \%)$ & $2(1.9 \%)$ \\
\hline Widowed & $1(2.0 \%)$ & $2(1.9 \%)$ \\
\hline Height $(m)^{b}$ & $1.59(0.24)$ & $1.59(0.18)$ \\
\hline Weight $(\mathbf{k g})^{b}$ & $67.62(12.18)$ & $68.09(12.61)$ \\
\hline BMI $\left(\mathrm{kg} / \mathrm{m}^{2}\right)^{\mathrm{b}}$ & $25.58(3.93)$ & $26.26(4.46)$ \\
\hline $\begin{array}{l}\text { Abdominal } \\
\text { circumference }(\mathrm{cm})^{\mathrm{b}}\end{array}$ & $84.52(12.00)$ & $87.48(12.48)$ \\
\hline QRDM (score) ${ }^{b}$ & $7.80(5.16)$ & $9.27(5.30)$ \\
\hline DKN-A (score) ${ }^{b}$ & $7.94(2.58)$ & $7.63(2.69)$ \\
\hline
\end{tabular}

aValues presented as absolute number (percentage); ${ }^{b}$ Values presented as mean (standard deviation)

$\mathrm{BMI}=$ body mass index; QRDM = Diabetes Mellitus Risk Questionnaire; DKN-A = Diabetes Knowledge Scale. 
of the present study. The following significant $(\mathrm{P}<0.05)$ and adequate correlations with this validation criterion were observed: QRDM ( $\mathrm{r}=0.686)$ and DKN-A $(\mathrm{r}=-0.216)$. According to COSMIN, values $\geq 0.50$ are expected for correlations of questionnaire scores with similar constructs (as in the case of QRDM) and values $<0.30$ for correlations of questionnaire scores with unrelated constructs (as in the case of DKN-A).

\section{Ceiling and floor effects}

Two individuals (1.9\%) achieved a FINDRISC minimum score of 0 . No participant reached the maximum score of 26 points. Therefore, ceiling and floor effects were not observed.

\section{DISCUSSION}

We observed that the FINDRISC in Brazilian Portuguese presented an adequate level of comprehension in the study population and acceptable values for reliability, internal consistency and validity. Regarding reliability, our study found kappa values (when considered item-by-item) ranging from 0.66 to 1.00 and ICC values (when considering the total score) of 0.98 . In addition, Cronbach's alpha of 0.84 was found. Significant correlations were found between the FINDRISC and DKN-A and between the FINDRISC and QRDM.

The FINDRISC has also been considered to be a valid questionnaire in other countries. However, these validations did not

Table 2. Translation, consensus version and backtranslation of Finnish Diabetes Risk Score (FINDRISC)

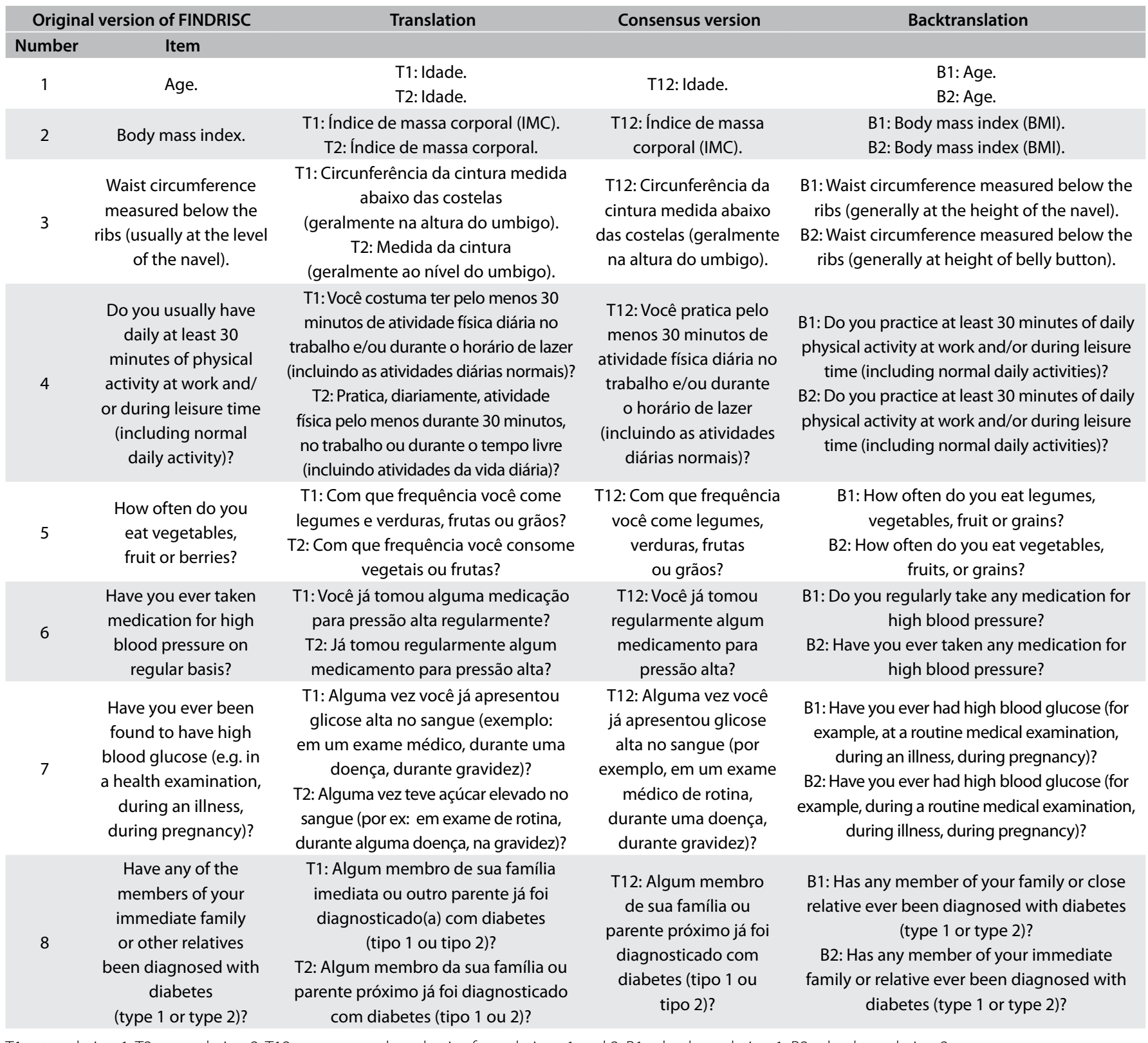

$\mathrm{T} 1=$ translation $1 ; \mathrm{T} 2=$ translation 2;T12 = consensual synthesis of translations 1 and 2; $\mathrm{B} 1=$ backtranslation $1 ; \mathrm{B} 2=$ backtranslation 2. 
Table 3. Finnish Diabetes Risk Score (FINDRISC) reliability and internal consistency with presentation of mean values, standard deviation (SD), kappa or intraclass correlation coefficient (ICC) with 95\% confidence interval (CI) and Cronbach's alpha

\begin{tabular}{|c|c|c|c|c|}
\hline \multirow{2}{*}{ FINDRISC item } & \multicolumn{2}{|c|}{ Mean (SD) } & \multirow{2}{*}{ Reliability } & \multirow{2}{*}{ Cronbach's alpha if item excluded } \\
\hline & Test & Retest & & \\
\hline 1 & $0.58(1.10)$ & $0.56(1.10)$ & kappa $=1.00(95 \% \mathrm{Cl}=1.00,1.00)$ & 0.83 \\
\hline 2 & $0.88(1.03)$ & $0.88(1.06)$ & kappa $=1.00(95 \% \mathrm{Cl}=1.00,1.00)$ & 0.83 \\
\hline 3 & $1.96(1.76)$ & $1.90(1.78)$ & kappa $=0.90(95 \% \mathrm{Cl}=0.85,0.95)$ & 0.82 \\
\hline 4 & $1.01(1.00)$ & $1.17(0.99)$ & kappa $=0.68(95 \% \mathrm{Cl}=0.61,0.74)$ & 0.84 \\
\hline 5 & $0.60(0.80)$ & $0.54(0.50)$ & kappa $=0.72(95 \% \mathrm{Cl}=0.65,0.78)$ & 0.84 \\
\hline 8 & $2.70(2.10)$ & $2.70(2.10)$ & kappa $=1.00(95 \% \mathrm{Cl}=1.00,1.00)$ & 0.83 \\
\hline Total score & $7.82(4.32)$ & $8.01(4.66)$ & $\mathrm{ICC}=0.98(95 \% \mathrm{Cl}=0.97,0.99)$ & Cronbach's alpha $=0.84$ \\
\hline
\end{tabular}

have cross-cultural translation and adaptation, and only tested the accuracy of diagnosing the risk of developing diabetes based on FINDRISC cutoff points. All of these studies used the receiver operating characteristic (ROC) curve as a statistical method. Thus, the following findings were observed: area under the ROC curve of 0.77 in Norway, ${ }^{19}$ greater than 0.70 in Venezuela, of 0.78 in Slovenia, ${ }^{20}$ of 0.74 in Mexico, ${ }^{27}$ of 0.76 in China, ${ }^{18}$ greater than 0.72 in Greece ${ }^{12}$ and greater than 0.74 in Spain. ${ }^{11}$ It is noteworthy that the values for the area under the ROC curve that were identified in these various studies established that the degree of accuracy of the FINDRISC was adequate.

The international best practices for translation, cross-cultural adaptation and validation of questionnaires are centered on COSMIN. ${ }^{22}$ These methodological guidelines indicate several psychometric properties that an instrument should present, with emphasis on i) reliability and ii) validity (composed of several subitems, such as face, content, construct, structural, cross-cultural and criterion validity) and responsiveness. Our validation study involved assessments of reliability (using kappa, ICC, SEM and MDC), cross-cultural adaptation (using translation, synthesis of translations, back-translation, expert committee and pre-final testing), construct validity (using the correlation between questionnaires) and structural validity (using Cronbach's alpha). These properties ensured that the FINDRISC can be applied to the Brazilian population. Other questionnaire validation studies conducted in Brazil have also measured these psychometric properties. ${ }^{28-30}$

Some limitations of this study and suggestions need to be noted. Firstly, we recommend that the cross-cultural adaptation of the FINDRISC to other languages should be tested based on COSMIN. ${ }^{22}$ Lack of such testing greatly limited the discussion of the results. In addition, because of the need for specific methodology, our study did not investigate the accuracy or responsiveness of the FINDRISC. Thus, we suggest that future studies should measure these psychometric properties in Brazilian Portuguese.

\section{CONCLUSION}

The results from this study demonstrate that the Brazilian Portuguese version of the FINDRISC has adequate psychometric properties that are in accordance with the best international recommendations. Thus, its use within clinical routines and/or research can be supported.

\section{REFERENCES}

1. Brazil country report 2010 - 2045. Available from: https://www. diabetesatlas.org/data/en/country/27/br.html. Accessed in 2019 (Dec 19).

2. Gallasch CH, Alexandre NMC, Esteves SCB. Propriedades psicométricas do questionário de avaliação de desempenho no trabalho em trabalhadores submetidos à radioterapia [Psychometric properties of the Brazilian version of the Work Role Functioning Questionnaire evaluating workers in radiotherapy]. Rev Enferm UERJ. 2015;23(6):81725. doi: 10.12957/reuerj.2015.15791.

3. Cruz PA. Adaptação transcultural do questionário de risco para diabetes mellitus: Take the test. Know your score [dissertation]. São Paulo: Universidade de São Paulo; 2010. doi: 10.11606/D.6.2010.tde13102010-144009.

4. Curcio R, Alexandre NMC, Torres H de C, Lima MHM. Tradução e adaptação do "Diabetes Distress Scale - DDS" na cultura brasileira. Acta Paul Enferm. 2012;25(5):762-7. doi: 10.1590/S0103-21002012005000025.

5. Torres HC, Virginia AH, Schall VT. Validação dos questionários de conhecimento (DKN-A) e atitude (ATT-19) de Diabetes Mellitus [Validation of Diabetes Mellitus knowledge (DKN-A) and attitude (ATT-19) questionnaires]. Rev Saude Publica. 2005;39(6):906-11. PMID: 16341399; doi: 10.1590/s0034-89102005000600006.

6. Correr CJ, Pontarolo R, Melchiors AC, et al. Tradução para o português e validação do instrumento Diabetes Quality of Life Measure (DQOL-Brasil) [Translation to Portuguese and validation of the diabetes quality of life measure (DQOL-Brazil)]. Arq Bras Endocrinol Metabol. 2008;52(3):515-22. PMID: 18506277; doi: 10.1590/s000427302008000300012. 
7. Michels MJ, Coral MH, Sakae TM, Damas TB, Furlanetto LM. Questionário de Atividades de Autocuidado com o Diabetes: tradução, adaptação e avaliação das propriedades psicométricas [Questionnaire of Diabetes Self-Care Activities: translation, cross-cultural adaptation and evaluation of psychometric properties]. Arq Bras Endocrinol Metabol. 2010;54(7):644-51. PMID: 21085770; doi: 10.1590/s000427302010000700009.

8. Lindström J, Tuomilehto J. The diabetes risk score: a practical tool to predict type 2 diabetes risk. Diabetes Care. 2003;26(3):725-31. PMID: 12610029; doi: 10.2337/diacare.26.3.725.

9. de Oliveira Araújo L, e Silva ES, de Oliveira Mariano J, et al. Risco para desenvolvimento do diabetes mellitus em usuários da atenção primária a saúde: um estudo transversal [Risk of developing diabetes mellitus in primary care health users: a cross-sectional study]. Rev Gaucha Enferm. 2015;36(4):77-83. PMID: 26735762; doi: 10.1590/19831447.2015.04.50195

10. Cândido JAB, Torres GMC, Figueiredo IDT, et al. FINDRISK: estratificação do risco para Diabetes Mellitus na saúde coletiva. Rev Bras em Promoção da Saúde. 2017;30(3):1-8. doi: 10.5020/18061230.2017.6118.

11. Soriguer F, Valdés S, Tapia MJ, et al. Validación del FINDRISC (FINnish Diabetes Risk SCore) para la predicción del riesgo de diabetes tipo 2 en una población del sur de España. Estudio Pizarra [Validation of the FINDRISC (FINnish Diabetes Risk SCore) for prediction of the risk of type 2 diabetes in a population of southern Spain. Pizarra Study). Med Clin (Barc). 2012;138(9):371-6. PMID: 21939990; doi: 10.1016/j. medcli.2011.05.025.

12. Makrilakis K, Liatis S, Grammatikou S, et al. Validation du questionnaire finlandais calculant un score de risque de diabète (FINDRISC) pour le dépistage du diabète de type 2 , des anomalies de la glycorégulation et du syndrome métabolique en Grèce [Validation of the Finnish diabetes risk score (FINDRISC) questionnaire for screening for undiagnosed type 2 diabetes, dysglycaemia and the metabolic syndrome in Greece]. Diabetes Metab. 2011;37(2):144-51. PMID: 21144787; doi: 10.1016/j. diabet.2010.09.006.

13. Nieto-Martínez R, González-Rivas JP, Ugel E, et al. External validation of the Finnish diabetes risk score in Venezuela using a national sample: The EVESCAM. Prim Care Diabetes. 2019;13(6):574-82. PMID: 31202539; doi: 10.1016/j.pcd.2019.04.006.

14. Acosta T, Barengo NC, Arrieta A, Ricaurte C, Tuomilehto JO. A demonstration area for type 2 diabetes prevention in Barranquilla and Juan Mina (Colombia): Baseline characteristics of the study participants. Medicine (Baltimore). 2018;97(1):e9285. PMID: 29505512; doi: 10.1097/ MD.0000000000009285.

15. Winkler G, Hídvégi T, Vándorfi G, Balogh S, Jermendy G. Prevalence of undiagnosed abnormal glucose tolerance in adult patients cared for by general practitioners in Hungary. Results of a risk-stratified screening based on FINDRISC questionnaire. Med Sci Monit. 2013;19:67-72. PMID: 23344680; doi: 10.12659/msm.883747.
16. Bergmann A, Li J, Wang L, et al. A simplified Finnish diabetes risk score to predict type 2 diabetes risk and disease evolution in a German population. Horm Metab Res. 2007;39(9):677-82. PMID: 17846976; doi: 10.1055/s-2007-985353.

17. Al-Shudifat AE, Al-Shdaifat A, Al-Abdouh AA, et al. Diabetes Risk Score in a Young Student Population in Jordan: A Cross-Sectional Study. J Diabetes Res. 2017;2017:8290710. PMID: 28540309; doi: 10.1155/2017/8290710.

18. Zhang $M$, Zhang $H$, Wang $C$, et al. Development and validation of a risk-score model for type 2 diabetes: A cohort study of a rural adult Chinese population. PLoS One. 2016;1 1(4):e0152054. PMID: 27070555; doi: 10.1371/journal.pone.0152054.

19. Jølle A, Midthjell K, Holmen J, et al. Validity of the FINDRISC as a prediction tool for diabetes in a contemporary Norwegian population: a 10-year follow-up of the HUNT study. BMJ Open Diabetes Res Care. 2019;7(1):e000769. PMID: 31803483; doi: 10.1136/bmjdrc-2019-000769.

20. Štiglic G, Fijačko N, Stožer A, Sheikh A, Pajnkihar M. Validation of the Finnish Diabetes Risk Score (FINDRISC) questionnaire for undiagnosed type 2 diabetes screening in the Slovenian working population. Diabetes Res Clin Pract. 2016;120:194-7. PMID: 27592167; doi: 10.1016/j. diabres.2016.08.010

21. Beaton DE, Bombardier C, Guillemin F, Ferraz MB. Guidelines for the process of cross-cultural adaptation of self-report measures. Spine (Phila Pa 1976). 2000;25(24):3186-91. PMID: 11124735; doi: 10.1097/00007632200012150-00014

22. Prinsen CAC, Mokkink LB, Bouter LM, et al. COSMIN guideline for systematic reviews of patient-reported outcome measures. Qual Life Res. 2018;27(5):1147-57. PMID: 29435801; doi: 10.1007/s11136-0181798-3.

23. Ramada JM, Serra C, Amick BC 3rd, et al. Reliability and validity of the work role functioning questionnaire (Spanish version). J Occup Rehabil. 2014;24(4):640-9. PMID: 24389721; doi: 10.1007/s10926-013-9495-0.

24. Sim J, Wright CC. The kappa statistic in reliability studies: use, interpretation, and sample size requirements. Phys Ther. 2005;85(3):25768. PMID: 15733050

25. Fleiss JL. The Design and Analysis of Clinical Experiments. Hoboken, USA: John Wiley \& Sons, Inc:; 1999. ISBN: 978-0-471-34991-4.

26. Ostelo RWJ, de Vet HC, Knol DL, van den Brandt PA. 24-item RolandMorris Disability Questionnaire was preferred out of six functional status questionnaires for post-lumbar disc surgery. J Clin Epidemiol. 2004;57(3):268-76. PMID: 15066687; doi: 10.1016/j.jclinepi.2003.09.005.

27. Arellano-Campos O, Gómez-Velasco DV, Bello-Chavolla OY, et al. Development and validation of a predictive model for incident type 2 diabetes in middle-aged Mexican adults: the metabolic syndrome cohort. BMC Endocr Disord. 2019;19(1):41. PMID: 31030672; doi: 10.1186/ s12902-019-0361-8

28. da Cunha RA, Costa LO, Hespanhol Junior LC, et al. Translation, crosscultural adaptation, and clinimetric testing of instruments used to assess patients with patellofemoral pain syndrome in the Brazilian population. 
J Orthop Sports Phys Ther. 2013;43(5):332-9. PMID: 23485881; doi: 10.2519/jospt.2013.4228.

29. Wageck BB, de Noronha M, Lopes AD, et al. Cross-cultural adaptation and measurement properties of the Brazilian Portuguese Version of the Victorian Institute of Sport Assessment-Patella (VISA-P) scale. J Orthop Sports Phys Ther. 2013;43(3):163-71. PMID: 23321783; doi: 10.2519/ jospt.2013.4287.

30. Manzoni ACT, Fagundes FRC, Fuhro FF, Cabral CMN. Translation, Cross-cultural Adaptation to Brazilian Portuguese, and Analysis of Measurement Properties of the Consultation and Relational Empathy Measure. J Chiropr Med. 2019;18(2):106-14. PMID: 31367197; doi: 10.1016/j.jcm.2018.10.005.

Authors' contributions: Conceição ALO: conceptualization (equal), data curation (equal), formal analysis (equal) and writing-original draft (equal); Corrêa NC: investigation (equal), methodology (equal) and writing-original draft (equal); Ferreira PR: data curation (equal), formal analysis (equal), project administration (equal) and writingreview \& editing (equal); Rêgo AS: formal analysis (equal), investigation (equal), methodology (equal) and writing-review \& editing (equal); Silva FB: formal analysis (equal), investigation (equal), methodology (equal) and writing-original draft (equal); de Carvalho RF: data curation (equal), formal analysis (equal), methodology (equal) and writingreview \& editing (equal); Dias RS: data curation (equal), formal analysis (equal), methodology (equal) and writing-original draft (equal); Paz BKB: investigation (equal), methodology (equal), supervision (equal) and writing-review \& editing (equal); Rocha VCC: conceptualization (equal), investigation (equal), methodology (equal), supervision (equal) and writing-original draft (equal); and Bassi-Dibai D: conceptualization (equal), methodology (equal), project administration (equal), supervision (equal) and writing-review \& editing (equal). All authors approved the final version of the manuscript for publication

Sources of funding: No grants or funding sources

Conflict of interest: The authors declare that there was no conflict of interest

Date of first submission: December 21, 2019

Last received: December 21, 2019

Accepted: March 5, 2020

\section{Address for correspondence:}

Daniela Bassi-Dibai

Programa de Pós-graduação em Gestão de Programas e Serviços de Saúde, Universidade Ceuma (UNICEUMA)

R. Josué Montello, 1

Jardim Renascença - São Luís (MA) — Brasil

CEP 65075-120

E-mail: danielabassifisio@gmail.com 
Appendix 1. Brazilian Portuguese version of Finnish Diabetes Risk Score (FINDRISC), initial page.

\section{AVALIAÇÃO DE RISCO DE DIABETES TIPO 2}

Circule a alternativa correta e some os seus pontos.

1. Idade

0 p. Abaixo de 45 anos

2 p. $\quad$ Entre $45-54$ anos

3 p. $\quad$ Entre 55-64 anos

4 p. $\quad$ Acima de 64 anos

2. Índice de massa corporal (IMC)

(Ver verso do formulário)

0p. Abaixo de $25 \mathrm{~kg} / \mathrm{m}^{2}$

1 p. $\quad 25-30 \mathrm{~kg} / \mathrm{m}^{2}$

3p. Acima de $30 \mathrm{~kg} / \mathrm{m}^{2}$

3. Circunferência da cintura medida abaixo das costelas (geralmente na altura do umbigo) HOMENS MULHERES

Op. Menor que $94 \mathrm{~cm}$ Menor que $80 \mathrm{~cm}$

3p. $\quad 94-102 \mathrm{~cm} \quad 80-88 \mathrm{~cm}$

$4 \mathrm{p}$. Maior que $102 \mathrm{~cm}$ Maior que $88 \mathrm{~cm}$

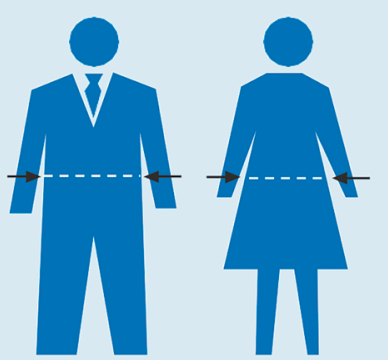

4. Você pratica pelo menos 30 minutos de atividade física diária no trabalho e/ou durante o horário de lazer (incluindo as atividades diárias normais)?

op. Sim

$2 \mathrm{p} . \quad$ Não

5. Com que frequência você come legumes, verduras, frutas ou grãos?

$0 \mathrm{p}$. Todos os dias

$1 \mathrm{p} . \quad$ Não todos os dias
6. Você já tomou regularmente algum medicamento para pressão alta?

Op. Não

2p. Sim

7. Alguma vez você já apresentou glicose alta no sangue (por exemplo, em um exame médico de rotina, durante uma doença, durante gravidez)?

$\begin{array}{ll}\text { 0p. } & \text { Não } \\ \text { 5p. } & \text { Sim }\end{array}$

8. Algum membro de sua família ou parente próximo já foi diagnosticado com diabetes (tipo 1 ou tipo 2)?

Op. Não

3p. Sim:avós, tia, tio ou primo de $1^{\circ}$ grau (exceto pai, mãe, irmão, irmã ou filhos)

5 p. Sim: pai, mãe, irmão, irmã ou filho

Pontuação Total de Risco

0 risco de desenvolver diabetes tipo 2 em 10 anos é:

Menor que 7 Baixo: cerca de 1 em cada 100 pessoas irá desenvolver a

7-11 Levemente elevado: cerca de 1 em cada 25 pessoas irá desenvolver a doença Moderado: cerca de 1 em cada 6 pessoas irá desenvolver a doença

15-20 Alto: cerca de 1 em cada 3 pessoas irá desenvolver a doença

Maior que 20 Muito alto: cerca de 1 em cada 2 pessoas irá desenvolver a doença 
Appendix 2. Brazilian Portuguese version of Finnish Diabetes Risk Score (FINDRISC), final page.

O QUE VOCÊ PODE FAZER

PARA DIMINUIR O SEU RISCO DE DESENVOLVER DIABETES TIPO 2?

Você não pode mudar sua idade ou sua predisposição genética. Entretanto, os outros fatores que predispõem ao diabetes, como sobrepeso, gordura abdominal, sedentarismo, hábitos alimentares e o hábito de fumar, dependem de você. Suas escolhas de estilo de vida podem evitar o diabetes tipo 2 ou pelo menos retardá-lo até uma idade mais avançada.

Caso haja alguém com diabetes na sua família, você deve atentar para não ganhar peso com o passar dos anos. $\mathrm{O}$ aumento da circunferência abdominal, em particular, aumenta o risco do diabetes, enquanto que a atividade física moderada diminui o risco. Você deve também ficar atento à sua dieta: consuma muitos produtos à base de cereais ricos em fibras e legumes todos os dias. Evite o excesso de gordura na sua dieta.
Os primeiros estágios do diabetes tipo 2 raramente apresentam sintomas. Se o seu total de pontos foi de 12 a 14 na Avaliação de Risco, você deve avaliar seriamente suas atividades físicas e hábitos alimentares e prestar atenção ao seu peso, para prevenir o desenvolvimento do diabetes. Não deixe de consultar o seu médico para mais informações e testes.

Se o seu total de pontos foi 15 ou mais na Avaliação de Risco, você deve fazer o teste de glicemia (em jejum e depois de uma dose de glicose ou após uma refeição) para determinar se você tem diabetes sem sintomas.

\section{ÍNDICE DE MASSA CORPORAL (IMC)}

O índice de massa corporal é usado para avaliar se uma pessoa está com o peso normal ou não. 0 índice é calculado dividindo-se o peso corporal (kg) pela altura ao quadrado $(\mathrm{m})$. Por exemplo, se a sua altura é $1,65 \mathrm{~m}$ e seu peso é $70 \mathrm{~kg}$, seu índice de massa corporal será $70 /(1,65 \times 1,65)$, o que resulta em 25,7.
Se o seu índice de massa corporal estiver entre 25 e 30 , você se beneficiará se perder peso ou ao menos deve se prevenir para que o seu peso não ultrapasse o atual. Se o seu índice de massa corporal for maior que 30 , os efeitos adversos da obesidade começarão a aparecer e será importante você perder peso.

TABELA: ÍNDICE DE MASSA CORPORAL

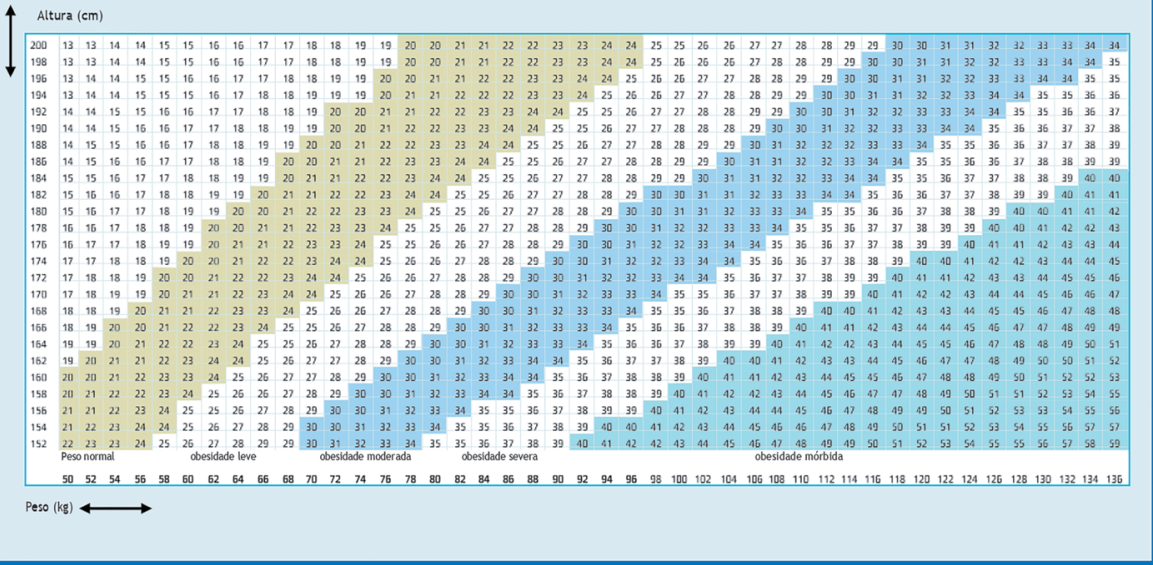

